\title{
Spices and Medicines Cultivated and Traded in Panama-City
}

\author{
I.M. Madaleno (a) \\ (a) Instituto de Geografia e Ordenamento do Território, Universidade de Lisboa isabel-madaleno@campus.ul.pt
}

\begin{abstract}
Urban agriculture (UA) is frequently perceived as an inadequate activity for a city. According to the United Nations, UA is an industry that produces, processes and markets food and fuel, largely in response to the daily demand of consumers within a city or metropolis, on land dispersed throughout the urban and peri-urban area, applying intensive production methods, using urban wastes and reusing water. This contribution doesn't focus exclusively the cultivation of food, spices and medicinal plant species on the capital city of Panama, but also the trade of American and exotic flora, and their uses. Following a scientific mission to the Central American country, the University of Lisbon conducted a survey to 50 informants, resident in Panama. Results from in-depth interviews gathered a total of 166 plants, corresponding to 171 different species, 96 of which had medicinal or cosmetic applications, 61 were consumed as food and 14 as spices
\end{abstract}

Keywords: Urban Geography, Circular Economy, Panama

\section{Resumo}

Especiarias e Plantas Medicinais Cultivadas e Comercializadas na Cidade do Panamá

A agricultura urbana (AU) é percepcionada como atividade inadequada para as cidades. De acordo com as Nações Unidas a AU é uma atividade destinada a produzir, processar e comercializar produtos alimentares que respondem a uma procura diária dos consumidores das cidades e das áreas metropolitanas, cultivados em parcelas urbanas e periurbanas, usando métodos intensivos, reciclando matéria orgânica proveniente dos lixos e reutilizando as águas residuais. Esta contribuição focará não exclusivamente a agricultura urbana praticada na cidade do Panamá, mas também a venda de especiarias, assim como plantas medicinais consumidas ou aplicadas externamente pelos residentes nesta cidade da América Central. A pesquisa realizada constou de 50 entrevistas, integradas num projecto de investigação científica realizado na América Latina. Os resultados mostram que os cidadãos do Panamá entrevistados utilizam um total de 166 plantas, correspondentes a 171 espécies botânicas diferentes, 96 das quais têm aplicações medicinais ou cosméticas, 61 são consumidas como alimento e 14 como especiarias.

Palavras chave: Geografia Urbana, Economia Circular, Panamá

\section{INTRODUCTION}

During the 1992 Rio Summit a new trend in urban development has been set, the Agenda 21, based on the concept of sustainability established in the 1987 Brundtland report titled "Our Common Future" (Baffour Awuah \& Booth, 2014, Kaklauskas, et al., 2018). The process was continued at the 1996 UN City Summit in Istanbul with the Habitat Agenda (Deelstra, \& Girardet, 2000). Concomitantly the United Nations Development Programme conducted a series of surveys in Latin America, and elsewhere around the world (UNDP, 1996). References to urban farming in Panama City were scarce, but a special report about the existence of various forms of "aquaculture" within a publication series for Habitat II gave grounds to the expectation that in 2017 there should be some urban agriculture (UA) practises inside the urban agglomeration (UNDP, 1996, p. 111, 225). Of course the production of food, spices, medicinal species, as well as fruits is the most common form of gardening in urban areas, and that was exactly what the University of Lisbon survey found in Panama. Urban agriculture can be practised even in tiny front and backyards, in central neighbourhoods, as documented close to the entrance of an apartment block located in the Banking sector of the core capital city of Panama (see Fig. 1). This constitutes a circular economy case-study. 
Urban farming is increasingly considered an ecologically recommended activity, as the carbon footprint is lower when food production is closer to our doorstep (Deelstra, \& Girardet, 2000). But honestly, nobody expects that every single citizen starts growing food in pots on the balcony, begins creating flourishing food gardens on rooftop spaces, or then hang window boxes from high rise buildings; the expectation is that municipalities make idle plots available to urban gardeners, and promote community gardening within city limits (Baffour Awuah \& Booth, 2014, Kita, 2016). As Colin Sage (2012) reminded "reliance upon the market as the sole effective mechanism for the supply and demand of food requires every individual to possess the capacity to buy". In developing countries there is "an estimated one billion people (...) experiencing hunger and malnutrition because of their lack of entitlements through which to express demand for food" (Sage, 2012, p.2-3). Hence, UA can minimise foodinsecurity for vulnerable people (Madaleno, 2017).

The structure of the paper after this introduction is to explain the two-stage methodology, followed by the enumeration of the results, illustrated with tables and photos, and finalised with the concluding remarks. Temporal and spatial comparisons are provided, in order to make both the assessment of the evolution of urban gardening and farming in Panama City, founded in 1519, and to evaluate food, spices and medicinal plants consumed, vis a vis other Latin American (LA) urban agglomerations. This paper will contribute to build a database on the issue of useful flora growth and trade in LA cities.

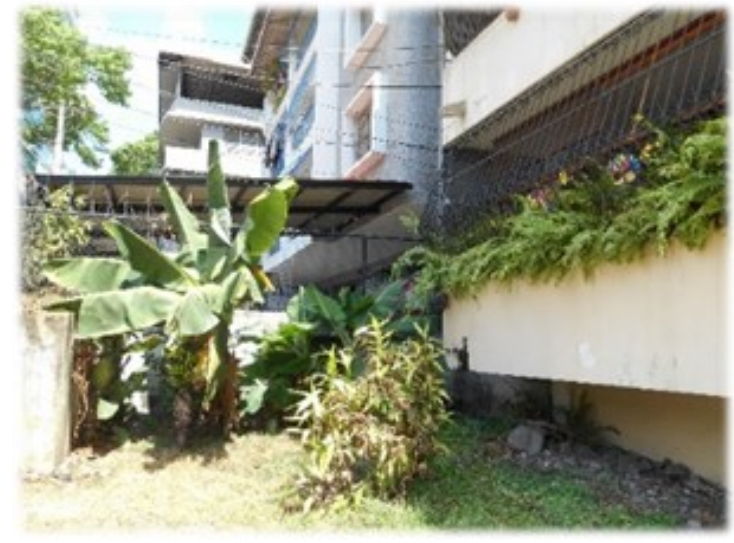

Figure 1 - Banana trees photographedin Panama City.

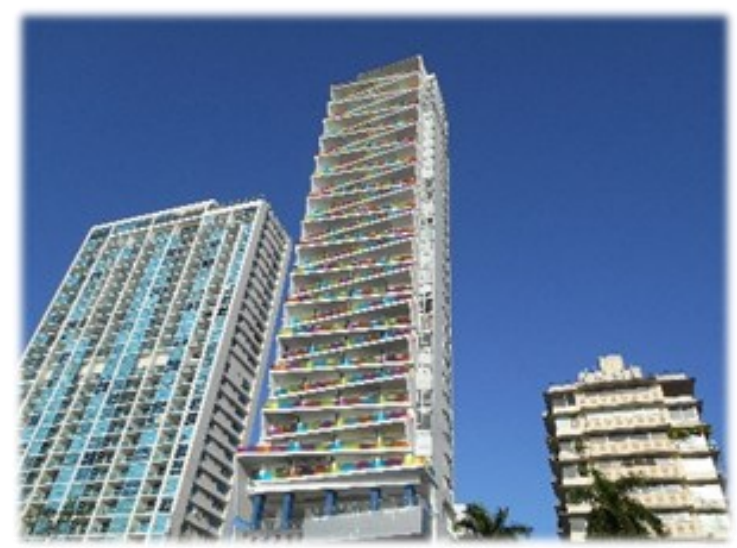

Figure 2 - High-rise buildings from the same capital city.

\section{MATERIALS AND METHODS}

The study followed the procedural sequence listed:

1. Archival examination of manuscripts from the early years of Spanish colonisation;

2. Fieldwork with a ramdom survey to flora consumption and trade conducted in early 2017, in Panama City, under the form of in-depth interviews to two categories of informants: i) urban gardeners, three of them responsible for food, spice and medicinal herbs growth and care; ii) Forty-seven formal and informal traders of fruits, spices, tubers, roots and herbal preparations, pharmacists and medicinal flora traders.

The sample gathered fifty testimonies using an open questionnaire similar to the one used in other Latin American and Asian surveys (Madaleno, 2017). Topics addressed were: the flora grown and traded; their uses; irrigation and fertilisation of the plot or pot planted species; the therapeutic recommendation, in case of medicinals; customers characterisation, in the trading posts; how native vegetables and staples were eaten, cooked or raw. Field observations and meetings with several informants from shopping malls provided clues as to the next locations to select, in a so-called snowball research process. That's the case with San Felipe Neri Market, the Central Market and the municipal plant nursery (Vivero Municipal), detailed in Table 1, which selection was recommended in the first interviews. Participation of respondents was always voluntary and their identity was not recorded.

The archival research was fundamental to make a qualitative evaluation of local flora sustainability, provid- 
ing the possibility to compare plant species mentioned in the 1526 manuscript of Gonzalo Fernández de Oviedo, with the ones consumed in our days (Gaibrois, 2002). Map in Figure 3 shows the location of the informants in a city map. The description of the survey is detailed in Table 1 . Latitude of this capital city is $8^{\circ} 58^{\prime} \mathrm{N}$, longitude is $79^{\circ} 31^{\prime} \mathrm{W}$ and average altitude is 10 metres above sea level. In 2016, the city had 1.544 .185 residents (INE, 2016). Cross-examination of flora consumption in the $16^{\text {th }}$ century and the 2017 survey results will be presented in the next pages.

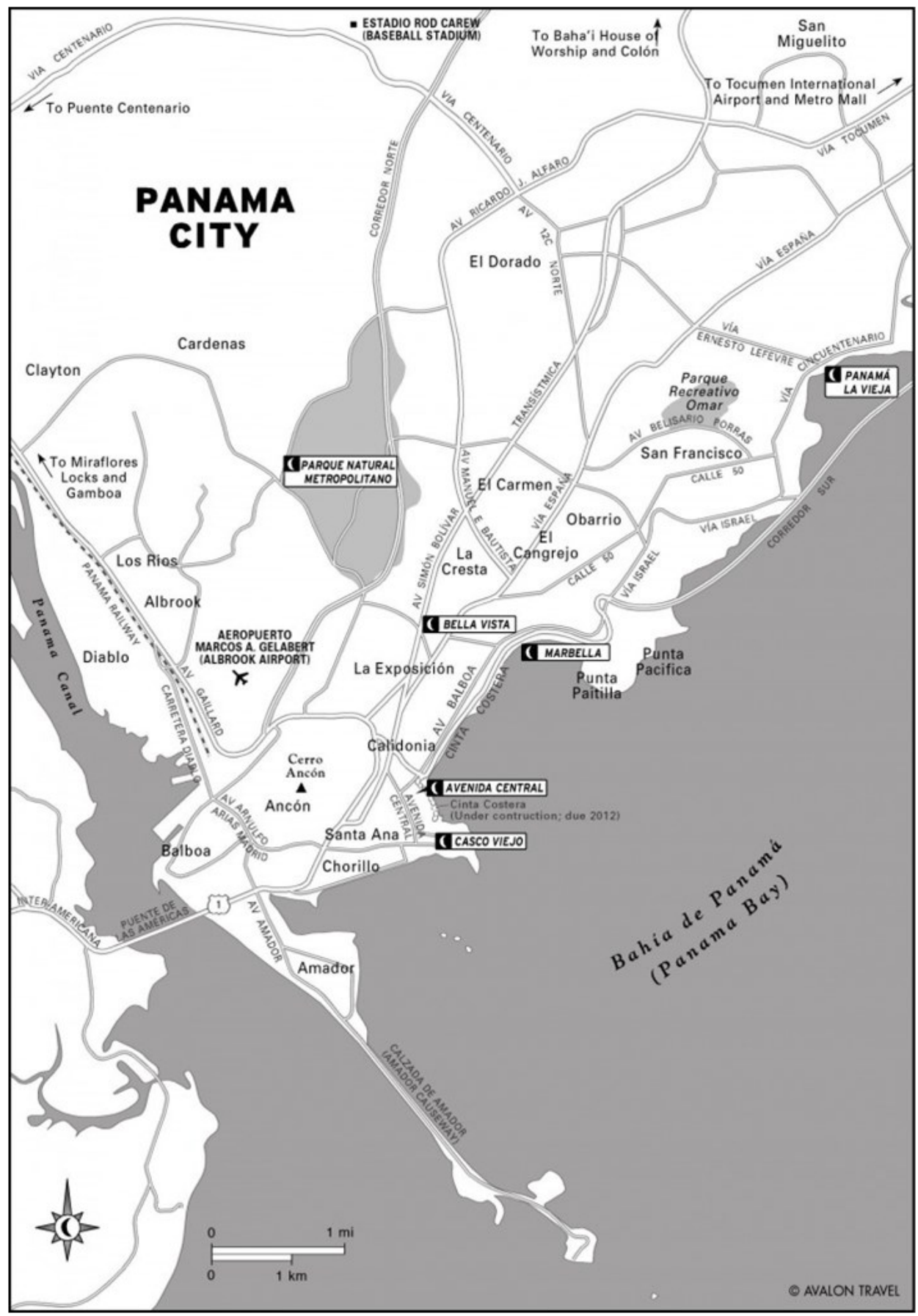

Figure 3 - Map of the city of Panama, with the location of the interview sites. Source: Google Maps. 
Table 1 - Survey Description and Location.

Source: Survey by Madaleno (2017)

\begin{tabular}{|c|c|c|c|c|}
\hline Location of the informants & $\begin{array}{c}\text { Number of } \\
\text { Interviews }\end{array}$ & $\%$ & Males & Females \\
\hline 1.Urban Cultivators (Via Israel) & 3 & 6 & 2 & 1 \\
\hline 2.Trading Posts & 47 & 94 & 19 & 28 \\
\hline $\begin{array}{c}\text { 2.1.San Felipe Neri Market } \\
\text { (Casco Viejo) }\end{array}$ & 3 & 6 & 1 & 2 \\
\hline $\begin{array}{c}\text { 2.2.Central Market } \\
\text { (La Exposición area) }\end{array}$ & 11 & 22 & 9 & - \\
\hline 2.3.Vivero municipal (outside the city map) & 1 & 2 & 1 & 5 \\
\hline 2.4.Multicentro Shopping (Marbella neigh- \\
bourhood)
\end{tabular}

\section{RESULTS AND DISCUSSION}

\subsection{First Result: The Useful Flora Grown During Renaissance in Panama}

The vernacular names of plants mentioned in the $16^{\text {th }}$ century manuscript authored by Oviedo totalled 55 , thirty-five of which (63.6\%) were native American or Asian fruits. Less than a half were consumed as food (40\%), and only four were used as medicine. Previous work cross-examined the top-ranking flora, their therapeutic applications and other uses in the $16^{\text {th }}$ century and in our days (Madaleno, 2017). Preferences for species with dual consumption patterns - such as coconuts (Cocos nucifera) and pineapples (Ananas comosus) - rivalled with the use of ají or Chilli peppers (Capsicum annuum) as spice and also as medicine. Rutaceae fruit trees were probably brought by the Spaniards, namely oranges (sweet and sour), lemons and citrons (Citrus medica). They were planted in their farms and city gardens, including by the Spanish traveller and historian Gonzalo Fernández de Oviedo (Gaibrois, 2002). These species are Eurasian or Asian in origin.

So, as first result the emphasis goes to 30 (54.5\%) vernaculars mentioned in the 1526 manuscript that are still common in modernity. As the French geographer Jean-Bernard Charrier wrote in his 1988 book on the issue of Cities and Countryside (Charrier, 1988), during renaissance numerous European towns mingled urban and rural activities, both animal husbandry and urban gardening, and thus it is not surprising that Latin American colonisers maintained the same habits, abroad. Therefore, the early Panamian cities, the capital of the country included, were green and biodiverse, as total rainfall registered is about 1,750 millimetres annually. Of course verticalisation in construction dominates in contemporaneity, as Figure 2 exemplifies.

\subsection{Second Result: Flora Consumed in Modernity}

The fifty in-depth interviews conducted in Panama City in early 2017 encountered 166 vernaculars corresponding to 171 different species of useful flora. The identification of the fruits, herbs, tubers, and roots gathered, used the Missouri Botanical Garden norm (MBG, 2018), which is available online. Ninety-six species recorded during fieldwork possessed at least one medicinal application (56.5\%); 60 vernaculars, corresponding to 61 species were consumed mainly as food (35.3\%); fourteen plant species were only utilised as spices. Table 2 presents this last category of aromatic flora, together with the number of occurrences, and the origin of the species, 
in order to illustrate the discussion of this second result (Cunha \& Roque, 2015).

Only a couple of aromatic plants were mentioned in the $16^{\text {th }}$ century manuscript by Oviedo (Gaibrois, 2002) and they were not identified as spices. Bay leaves were used in comparisons with newfound species, namely avocado tree leaves; albahaca or basil was used as local food, and it was probably the native Ocimum americanum, Family Lamiaceae, an herb of the same gender but American in origin (MBG, 2018). It is also important to emphasize that two Asian and Eurasian flora specimens, a tiny lemon and the coriander, are tagged as Chinese. That's because the construction of a railway from the Atlantic coast (Colón) to the Pacific (Panama City), in 1848, required about 7,000 immigrant workers from China, India, the Caribbean Islands, as well as Ireland and Spain (Ventocilla \& Dillon, 2010). The international contractors were the North-American Pacific Mail Company, and all these peoples left their imprint in the Central American country under study.

\subsection{Third Result: Staple Food Grown and Traded in 2017}

Food eaten in Panama contains a limited number of plant species, little more than $1 / 3$ of the flora gathered during the survey. Coconuts are the top-ranking fruits consumed, with 11 occurrences (6.4\%), against (3.5\%) for cosmetic and medicinal purposes, corresponding to $9.9 \%$. To this fruit mango follows suit, with 12 records as food (7\%), and two more as medicine, taken in refreshing infusions. Native American pineapple is ex-aequo, registering $7 \%$ of the occurrences, even though it possesses also medicinal properties, a fact already mentioned in Oviedo, in the $16^{\text {th }}$ century (Gaibrois, 2002). The staples range from potatoes (5 records), cassava (2.9\%), ñame ( $2.3 \%$ of the occurrences), corn $(2.3 \%)$, rice (1.8\% of the records), to sweet potatoes (1.8\%). Then come other basic food such as culantro (Eryngium foetidum, with $4.1 \%$ occurrences), peas (3.5\%), pumpkins (5 records or $2.9 \%$ ), green beans (3), lentils (2), and the local otoi (Xanthosoma sagittifolium), with another couple of occurrences (see Fig. 4).

Table 2 - Spices collected in Panama City.

Source: Survey by Madaleno (2017), Gaibrois, 2002.

\begin{tabular}{|c|c|c|c|c|}
\hline $\begin{array}{l}\text { Vernacular } \\
\text { Name } \\
\text { (English) }\end{array}$ & $\begin{array}{l}\text { Scientific } \\
\text { Name }\end{array}$ & Origin & Old uses & $\begin{array}{l}\mathrm{N}^{\circ} \text { in the } \\
\text { survey }\end{array}$ \\
\hline $\begin{array}{l}\text { Limón Mandarino } \\
\text { Chinese Lemon }\end{array}$ & $\begin{array}{c}\text { Citrofortunella microcarpa (Bunge) } \\
\text { Wijnands } \\
\text { RUTACEAE }\end{array}$ & Asian & - & 5 \\
\hline $\begin{array}{l}\text { Perejil } \\
\text { Parsley }\end{array}$ & $\begin{array}{c}\text { Petroselinum crispum (Mill.) Fuss } \\
\text { APIACEAE }\end{array}$ & Eurasian & - & 5 \\
\hline $\begin{array}{l}\text { Cilantro Chino } \\
\text { Coriander }\end{array}$ & $\begin{array}{l}\text { Coriandrum sativum L. } \\
\text { APIACEAE }\end{array}$ & Eurasian & - & 2 \\
\hline $\begin{array}{c}\text { Laurel } \\
\text { Bay Leaves }\end{array}$ & $\begin{array}{l}\text { Laurus nobilis L. } \\
\text { LAURACEAE }\end{array}$ & European & Leaf characterisation & 2 \\
\hline $\begin{array}{c}\text { Albahaca } \\
\text { Basil }\end{array}$ & $\begin{array}{l}\text { Ocimum basilicum L. } \\
\text { LAMIACEAE }\end{array}$ & European & Food & 1 \\
\hline $\begin{array}{l}\text { Estragón } \\
\text { Estragon }\end{array}$ & $\begin{array}{l}\text { Artemisia dracunculus L. } \\
\text { ASTERACEAE }\end{array}$ & Eurasian & - & 1 \\
\hline $\begin{array}{l}\text { Mejorana } \\
\text { Marjoram }\end{array}$ & $\begin{array}{c}\text { Origanum majorana } \mathrm{L} . \\
\text { LAMIACEAE }\end{array}$ & Eurasian & - & 1 \\
\hline $\begin{array}{l}\text { Mostaza } \\
\text { Mustard }\end{array}$ & $\begin{array}{c}\text { Brassica nigra (L.) W.D.J. Koch } \\
\text { BRASSICACEAE }\end{array}$ & Asian & - & 1 \\
\hline $\begin{array}{l}\text { Nuez Moscada } \\
\text { Nutmeg }\end{array}$ & $\begin{array}{c}\text { Myristica fragrans Houtt. } \\
\text { MYRISTICACEAE }\end{array}$ & Asian & - & 1 \\
\hline $\begin{array}{l}\text { Orégano } \\
\text { Oregano }\end{array}$ & $\begin{array}{l}\text { Origanum vulgare L. } \\
\text { LAMIACEAE }\end{array}$ & European & - & 1 \\
\hline
\end{tabular}




\subsection{Fourth Result: Flora no Longer in Use}

Table 3 presents eight "forgotten plants" consumed as food or presenting other uses normal in the beginning of European colonization, but uncommon these days. They range from flora whose shoots serve to make soap, like the plum bush; fruits used as cups, such as the Cucurbitaceae species lagenaria; leaves that covered and insulated roofs, like Caladium striatipes; and rope manufacture, in case of the Agave, both with the species sisalana and fourcroydes. The focus goes to a couple of renown medicines, anticipating the next result, the bark of guayacán tree, exported from Latin America to Europe and Asia, because it was used to cure syphilis; and annatto (Bixa orellana), used to paint the body in Oviedo's time, but still applied and even ingested in concoctions and infusions elsewhere in the America's (Madaleno, 2013). As to food species no longer consumed in Panama, bihaos or wild bananas were replaced by Musa paradisiaca, but genipap fruits are still used to make wine and liquor and the plum bush (Spondias mombim) to make refreshments, in Brazil (Cavalcante, 1991, Gomes, 1972).

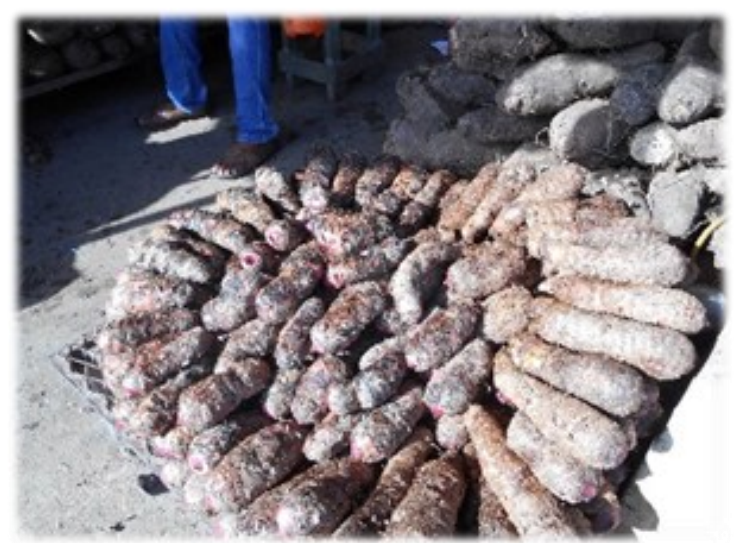

Figure 4 - Otoi or Malanga from a Panamian market.

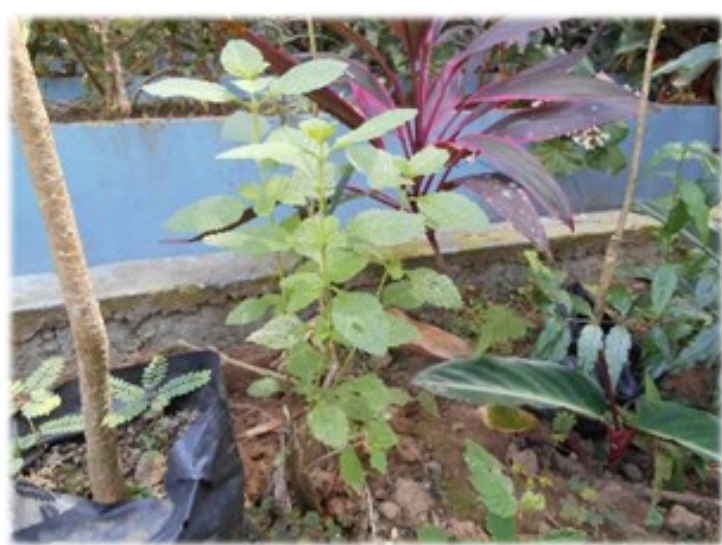

Figure 5 - Mastranto, grown both in pots and urban gardens.

\subsection{Fifth Result: The Growth of Medicines and its Trade in 2017}

More than half the useful flora gathered in the city of Panama had medicinal applications. The top-ranking species solely used for therapeutic purposes encountered during fieldwork was Aloe vera, with 16 records or $9.3 \%$ (Madaleno, 2017). Most of the applications were external, against baldness or to resolve skin problems, which differentiates this case-study from the previous Latin American research (Madaleno, 2012). In fact, in eight other countries (Argentina, Mexico, Costa Rica, Peru, Cuba, Chile, Uruguay and Brazil) Aloe sap was ingested with honey, whiskey, milk or lemon to prevent and even to treat cancer patients. It was consumed to control diabetes, and in Lima (Peru) it was applied to the eyes in case of cataracts (Madaleno, 2012, 2013). The World Health Organization (WHO) has successfully tested the species, recognising its analgesic, anti-fever, hypoglycaemic, anti-tumour and anti-asthmatic properties (WHO, 2009). Pharmacognosy researchers from Portugal also proved the species to have skin healing activities; it was approved in cosmetics as skin softener and considered to have anti-inflammatory properties (Cunha, Silva \& Roque, 2003).

Next comes the native American Chilli pepper (Capsicum annuum), consumed as immune health supplement (8 reports) and as spice (6 occurrences) totalling $8.2 \%$ of the records (Madaleno, 2017). Lemons and citrons (Citrus micrantha and medica), are third (13 occurrences or 7.6\%), applied to the skin for body shaping or as butter creams to the hair. They are consumed as food, either (5.8\% records). Chamomile, with 12 occurrences, goes fourth, and again the cosmetic external usage in hydrating creams is remarkable, but it is recommended for better blood circulation, too. Anti-inflammatory activity was also registered by WHO (WHO, 1999). The plant species is sold fresh in local markets, natural pharmacies, as well as in supermarkets, and under the form of small portions packed for infusion making. This practise was found in other Latin American agglomerations, such as in San José, neighbouring Costa Rica; in Havana, Cuba; in Mexico City, Cuernavaca and Puebla, in Mexico (Cunha, Silva \& Roque, 2003).

Green and black tea (Thea sinensis) are ex-aequo with chamomile, the former being consumed for weightreduction. Figure 5 illustrates Vernonia condensata species, gardened in Panama (2 records, as in Fig. 6), whose 
leaves are consumed in infusions against diarrhoea. Previous fieldwork conducted in St. Louis, Brazil, in 2010, found the species to be planted for another purpose, namely to resolve stomach and hepatic troubles, after excessive drinking (Madaleno, 2011).

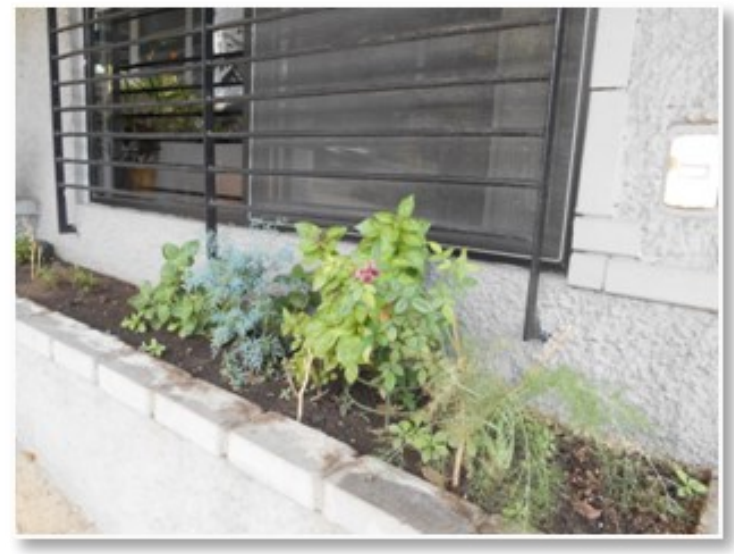

Figure 6 - Window pots in the city of Panama.

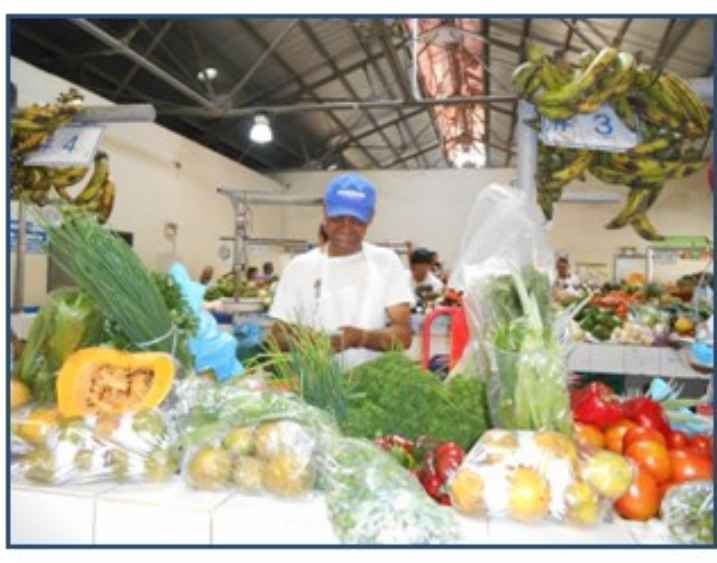

Figure 7 - San Felipe Neri Market fruit and vegetables trader.

Table 3 - Forgotten Flora in Panama.

Sources: Survey by Madaleno (2017); Gaibrois (2002)

\begin{tabular}{|c|c|c|c|}
\hline $\begin{array}{l}\text { Vernacular name } \\
\text { (English) }\end{array}$ & Scientific name & Uses in Oviedo's manuscript & $\begin{array}{c}\text { Contemporary uses in Latin } \\
\text { America }\end{array}$ \\
\hline $\begin{array}{c}\text { 1.Bihaos } \\
\text { Wild Banana }\end{array}$ & $\begin{array}{c}\text { Caladium striatipes (Kunth \& C.D. } \\
\text { Bouché) Schott. } \\
\text { ARACEAE }\end{array}$ & $\begin{array}{c}\text { Fruit and rhizome were food, } \\
\text { while the leaf covered the } \\
\text { shacks. }\end{array}$ & Not recorded \\
\hline $\begin{array}{l}\text { 2. Bija } \\
\text { Annatto }\end{array}$ & $\begin{array}{l}\text { Bixa Orellana L. } \\
\text { BIXACEAE }\end{array}$ & $\begin{array}{l}\text { Used to paint the body } \\
\text { together with genipap. }\end{array}$ & $\begin{array}{l}\text { Leaf and root infusion against } \\
\text { colds, asthma and sore throat } \\
\text { (Peru, Cuba). Seed and leaf } \\
\text { controls diabetes (Peru). Skin } \\
\text { application of the bark against } \\
\text { leprosy (Mexico, Peru), and } \\
\text { insect bites (Brazil, Costa Rica). }\end{array}$ \\
\hline 3.Cabuya & $\begin{array}{c}\text { Agave sisalana Perrine ex Engelm. } \\
\text { ASPARAGACEAE }\end{array}$ & Used to make ropes & Not recorded \\
\hline $\begin{array}{l}\text { 4. Guayacán, Palo Santo } \\
\text { Guaiacum }\end{array}$ & $\begin{array}{l}\text { Guaiacum officinale L. } \\
\text { ZYGOPHYLLACEAE }\end{array}$ & $\begin{array}{l}\text { The bark was used to cure } \\
\text { syphilis }\end{array}$ & Not recorded \\
\hline $\begin{array}{c}\text { 5. Genipapo } \\
\text { Genipap or Marmelade-box }\end{array}$ & $\begin{array}{l}\text { enipa americana } \mathrm{L} . \\
\text { RUBIACEAE }\end{array}$ & $\begin{array}{l}\text { Fruit good to eat. The juice is } \\
\text { used to wash the legs and to } \\
\text { paint the body. }\end{array}$ & Not recorded \\
\hline 6. Henequém & $\begin{array}{l}\text { Agave fourcroydes Lem. } \\
\text { ASPARAGACEAE }\end{array}$ & Used to make ropes. & Not recorded \\
\hline 7. Higuero, guira, guiro & $\begin{array}{l}\text { Cucurbita lagenaria } \mathrm{L} . \\
\text { CUCURBITACEAE }\end{array}$ & $\begin{array}{l}\text { The fruit is good to make } \\
\text { cups. }\end{array}$ & Not recorded \\
\hline $\begin{array}{l}\text { 8. Hobos, jojos } \\
\text { Plum Bush }\end{array}$ & $\begin{array}{l}\text { Spondias mombin } \mathrm{L} \text {. } \\
\text { ANACARDIACEAE }\end{array}$ & $\begin{array}{l}\text { Fruit is food. The shoots are } \\
\text { good to make soap and the } \\
\text { bark improves circulation. }\end{array}$ & Not recorded \\
\hline
\end{tabular}

\subsection{Sixth Result: Flora Consumed in 2017 and in 1526, and the Most Common Uses}

Table 4 cross-examines old and current uses in the city of Panama. Only the vernacular names are listed, referring to the analysis of Gonzalo Fernández de Oviedo's manuscript, but in case of the 2017 survey, the information presents all the plant species gathered during fieldwork. Results show that $40 \%$ of the flora mentioned in the $16^{\text {th }}$ century was referred to food plants or to other uses, which also integrates Eurasian species, introduced in Central America. In modernity, the medicinal applications dominate, with $56.5 \%$ of the records, whereas food plants constitute little more than $1 / 3$ of flora gathered (see fig. 7).

Even though native American flora is so rich, spices were by far imported. The exception goes to Chilli (Capsicum annuum), with 6 records, which presented mixed uses. So, the emphasis should go to the importance of 
plant species introduced during European colonisation or later on, as input of a vague of immigrant workers to Panama. The staple foods, by contrast, included a vast array of native tubers, roots and fruits, widely consumed in the city. Following the trend of previous research missions to Latin America, medicinal flora recorded was quite numerous, standing first in the ranking of preferences. External applications deserve being stressed, as cosmetic uses of flora predominated.

Table 4 - Cross-Examination of Uses, Today and in the Past. Sources: Survey by Madaleno (2017); Gaibrois (2002)

\begin{tabular}{|c|c|c|c|c|}
\hline Uses and Origin & No of Oviedo's Vernaculars & $\%$ & $\begin{array}{c}2017 \text { Survey Plant } \\
\text { Species }\end{array}$ & $\%$ \\
\hline Food & 22 & 40.0 & 61 & 35.7 \\
\hline Medicines & 4 & 7.3 & 96 & 8.2 \\
\hline Spices & 9 & 16.3 & 14 & - \\
\hline Other Uses & 20 & 36.3 & - & 171 \\
\hline Total & 55 & 99.9 & & 100 \\
\hline
\end{tabular}

\section{CONCLUSIONS}

Farming within the urban tissue contributes to diminish the heat island, produces oxygen, and infiltration spaces that minimise flood-risks. In socio-economic terms, it is an opportunity to cope with famine and poverty, providing ways to give the less wealthy households food-security. Urban agriculture is a reconciliatory activity, both with nature and with the city, the so-called urban jungle. It is also a good opportunity to develop the socalled seven Rs, as it provides the opportunity to refuse the idea that a city only produces waste, introducing new concepts as to re-gift or sell used goods, but in case of UA, the proposal is: to reduce the citizens carbon footprint; to reuse waters, as the ones that wash vegetables in the kitchen; to reutilise organic wastes in fertilization; to recycle garbage; to rethink the utilisation of common condominium spaces (as illustrated in Fig. 1); to recuperate window and balcony spaces to grow food, spices and medicinal plants, even ornamental herbs (as shown in Fig. 1 and 6), thus practicing a circular economy.

Research findings reveal that $14.5 \%$ of plants mentioned in Oviedo's "Summary of The Natural History of the Indies" are no longer in use in Panama; yet they do not possess a vulnerable status. In fact, it should be stressed that European colonisation contributed to enrich flora grown and traded in Panama, and so did several vagues of migrants to the capital city and surroundings. Conclusion is that even in capital cities known for their financial status as fiscal paradises, it is possible to observe adhesion to sustainable agriculture and trade practices, which record contributes to give us hope that useful flora will not be depleted in the near future in Panama.

\section{REFERENCES}

BAFFOUR AWUAH, K. G. \& BOOTH, C.A. (2014). Integrated management framework for sustainable cities: insights into multiple concepts and principles. WIT Transactions on Ecology and the Environment, 191, 111-123.

CAVALCANTE, P.B. (1991). Frutas Comestiveis da Amazônia. Belém, Brazil: Museu Paraense Emílio Goeldi/CEJUP.

CHARRIER, J.-B. (1988). Villes et Campagnes. Paris, France: Masson.

CUNHA, A.P.\& ROQUE, O.R. (2015). Especiarias e Plantas Condimentares. Origem, Composição e Utilizações. Lisboa, Portugal: Fundação Calouste Gulbenkian.

CUNHA, A.P., SILVA, A.P. \& ROQUE, O.R. (2003). Plantas e produtos vegetais em fitoterapia. Lisboa, Portugal: Fundação Calouste Gulbenkian.

DEELSTRA, T. \& GIRARDET, H. (2000). Urban agriculture and Sustainable Cities. In. N. Bakker, M. Dubbeling, S. Gundel, U. Sabel-Koschella, H. de Zeeuw (Eds.), Growing Cities, Growing Food (pp. 43-65). Feldafing, Germany: Deutsche Stiftung fur Internationale Entwicklung.

GAIBROIS, M.B. (2002). Sumario de la Natural Historia de las Indias de Gonzalo Fernández de Oviedo. Madrid, Spain: Dastin. 
GOMES, R.P. (1972). Fruticultura Brasileira. S. Paulo, Brazil: Nobel.

INE (2016). Población. Ciudad de Panamá, Panamá: Instituto Nacional de Estadísticas. Retrieved from https:// www.contraloria.gob.pa/inec/archivos/P85512\%20\%20Poblaci\%C3\%B3n\%21.pdf

KAKLAUSKAS, A., ZAVADSKAS, E.K., RADZEVICIENE, A., UBARTE, I., PODVIESKO, A. PODVESKO, V., KUZMINSKE, A., BANAITIS, A., BINKYTE, A., BUCINSKAS, V. (2018). Quality of City Life Multiple Criteria Analysis. Cities, 72, 82-93.

KITA, K. (2016). Multi-stakeholder Policy Influencing and Local Urban Food Initiatives. Urban Agriculture Magazine, 31, $16-17$.

MADALENO, I.M. (2013). Estudo Etnogeográfico de Plantas Medicinais da América Latina. Lisboa: Lisboa, Portugal: Alêtheia Editores.

MADALENO, I. (2017 September). Flora Grown and Traded in Panama City, in the $16^{\text {th }}$ Century and Nowadays. Paper presented at the Deutscher Tropentag Conference. Retrieved from http://www.tropentag.de/2017/abstracts/full/34.pdf.

MADALENO, I.M. (2012). Organic cultivation and use of medicinal plants in Latin America. Pharmacognosy Communications, 2 (4), 34-51.

MADALENO, I.M. (2011). Plantas da Medicina Popular de São Luís, Brasil. Boletim do Museu Paraense Emílio Goeldi. Ciências Humanas, 6 (2), 273-286.

MBG (2018). Missouri Botanical Garden. Retrieved from http://www.tropicos.org.

SAGE, C. (2012). Environment and Food. Abingdon, UK: Routledge.

UNDP (1996). Urban Agriculture. Food, Jobs and Sustainable Cities. New York, USA: United Nations Development Programme.

VENTOCILLA, J. \& DILLON, K. (2010). Gamboa. Una guía para su patrimonio natural y cultural. Panama City, Panama: Instituto Smithsonian de Investigaciones Tropicales.

WHO (2009). Medicinal plants in Papua New Guinea. Manila, The Phillippines: World Health Organization.

WHO (1999). WHO Monographs in Selected Medicinal Plants. Geneva, Switzerland: World Health Organization. 